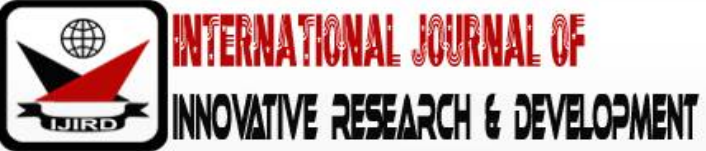

ISSN 2278 - 0211 (Online)

\section{Qualitative Analysis of Secondary Metabolites in Centaurea Senegalensis Plant}

\author{
Silas Ishaku \\ Lecturer, Department of Chemistry, College of Education Zing, Taraba State, Nigeria \\ Bolarin Joshua Adedeji \\ Lecturer Department of Chemical Sciences, College of Natural and Applied Sciences, \\ Salem University Lokoja, Kogi State, Nigeria \\ Filibus Irmiya \\ Lecturer, Department of Chemistry, College of Education Zing, Taraba, State, Nigeria
}

\begin{abstract}
:
The study was carried out to investigate the secondary metabolites of Centaurea senegalensis plant by conducting a phytochemical screening of four (4) extracts namely; n-hexane, dichloromethane, ethyl acetate and methanol using approved standard methods for phytochemical screening. The results showed the presence of tannins, flavonoids, steroids, glycosides, alkaloid and saponins in the extracts. The result showed the presence of steroids and glycosides in all the extracts, while triterpenoids and anthraquinones were absent in all the four (4) extracts investigated. The results confirmed that Centaurea senegalensis contains phytochemical properties for curing various ailments and also serves as a potential antioxidant.
\end{abstract}

Keywords: Qualitative analysis, metabolites, alkaloids, steroids, glycosides, tannins, flavonoids

\section{Introduction}

Medicinal plants have been the mainstay of traditional herbal medicine amongst rural dwellers worldwide since time immemorial. The therapeutic use of plants certainly goes back to the Sumerian and the Akkadian civilizations in about the third millennium BC (Mandal et al. 2005). One of the ancient authors, who described medicinal natural products of plant and animal origins, listed approximately 400 different plant species for medicinal purposes. Medicinal plants have always been considered as a source for healthy life for people. Therapeutic properties of medicinal plants are very useful in healing various diseases and the advantages of these medicinal plants are natural (Kalemba and Kunicka, 2003). Over the years they have assumed a very central stage in modern civilization as natural source of chemotherapy as well as amongst scientist in search for alternative sources of drugs.

About 3.4 billion people in the developing world depend on plant-based traditional medicines. This represents about 88 per cent of the world's inhabitants, who rely mainly on traditional medicine for their primary health care. According to the World Health Organization, a medicinal plant is any plant which, in one or more of its organs, contains substances that can be used for therapeutic purposes, or which are precursors for chemo-pharmaceutical semi synthesis. Such a plant will have its parts including leaves, roots, rhizomes, stems, barks, flowers, fruits, grains or seeds, employed in the control or treatment of a disease condition and therefore contains chemical components that are medically active. These non-nutrient's plant chemical compounds or bioactive components are often referred to as phytochemicals (phyto in Greek translation meaning 'plant') or phyto constituents are responsible for protecting the plant against microbial infections or infestations by pests (Doughariet al., 2009). The study of natural products on the other hand is called phytochemistry. Phytochemicals have been isolated and characterized from fruits such as grapes and apples, vegetables such as broccoli and onion, spices such as turmeric, beverages such as green tea and red wine, as well as many other sources (Doughari, 2009). The science of application of these indigenous or local medicinal remedies including plants for treatment of diseases is currently called ethno pharmacology but the practice dates back since antiquity.

A plant in which one or more of its organs contains substances that can be used for therapeutic purposes on which are precursors for the synthesis of useful drugs are called medicinal plants. Medicinal plants contain biologically active chemical substances (phytochemicals) such as saponins, tannins, essential oils, flavonoids, alkaloids and other chemical compounds, which have preventive and curative properties. These complex chemical substances of different compositions are found as secondary plant metabolites in one or more of these plants and are useful for humanity (Okigbo, 2000). In view of many diseases defiling drugs, health practices are now changing from curative to preventive medicine. Phytochemicals popular in preventive medicine are flavonoids, polyphenols, saponins, lignoids and vitamins. Also, a knowledge of the chemical constituents of plants is desirable, not only for the discovery of therapeutic agents, but also because such information may be of value in disclosing new sources of such economic materials as tannins, oils, gums, which are precursors for the synthesis of complex chemical substances, etc. In addition, the knowledge of the chemical 
constituents of plants would further be valuable in discovering the actual value of folkloric remedies. This study was carried out to investigate the secondary metabolites of Centaurea senegalensisis plant.

\section{Materials and Methods}

\subsection{Materials, Equipment and Apparatus for the Study}

Test tubes, Test tube racks, Measuring cylinder (10mL), Volumetric flask, Funnel, Bottles, Filter paper, Water bath, Glass rod, Spatula, Mortar, Pestle, Acetic anhydride, Concentrated $\mathrm{H}_{2} \mathrm{SO}$,Chloroform, Magnesium turnings, Concentrated HCL, Ferric chloride, Ammonia $\left(\mathrm{NH}_{3}\right)$, Benzene, Potassium Iodide( $\left.\mathrm{KI}\right)$, Mercuric chloride $\left(\mathrm{HgCl}_{2}\right)$, Iodine, and $10 \% \mathrm{H}_{2} \mathrm{SO}_{4}$ in methanol.

\subsection{Sample and Sampling Techniques}

Fresh plant of Centaurea senegalensis was identified, collected and authenticated by the herbarium unit of the Department of Biological Science, Ahmadu Bello University Zaria, Kaduna State, Nigeria. Voucher number of the plant was obtained to be 2052. The plant samples were air dried for two weeks and grounded to powder using mortar and pestle. The samples were kept in plastic container until required for analysis.

\subsection{Sample Preparation}

Air-dried and grounded plant of Centaurea senegalensis (240.1g) were extracted sequentially by cold maceration using solvent such as Hexane, Dichloromethane (DCM), Ethylacetate (EtOAc) and Methanol (MeOH) for two (2) weeks. The extracts were filtered using a filter paper and muslin cloth and thereafter concentrated under reduced pressure on a rotary evaporator at $45^{\circ} \mathrm{C}$ which afforded $4.6 \mathrm{~g}$ methanolas stated by Odebiyi A. and Sofowora A.E (1978)

\subsection{Reagents/ Chemicals}

All the reagents that are used in this work were of analytical; Ethanol (BDH chemicals Ltd Poole England), Hydrochloric acid, Mayer's reagent, Fehling's solution, Iron (III) Chloride solution, Sodium hydroxide, Wagners reagent.

\subsection{Preparation of Chemical/ Reagent}

- Wagner's reagent: $2 \mathrm{~g}$ of Iodine and $6 \mathrm{~g}$ of $\mathrm{KI}$ were dissolved in $100 \mathrm{~mL}$ of distilled water.

- Mayer's reagent: $1.3 \mathrm{~g}$ of $\mathrm{HCl}$ and $5 \mathrm{~g} \mathrm{KI}$ dissolved in $100 \mathrm{~mL}$ of distilled water

- Aqueous $\mathrm{HCl}(1.5 \%): 1.5 \mathrm{~mL}$ of concentrated $\mathrm{HCl}$ was dissolved in $100 \mathrm{ml}$ of distilled water

- Aqueous $\mathrm{FeCl}_{3}(5 \%): 5 \mathrm{~g} \mathrm{FeCl}_{3}$ was dissolved in $100 \mathrm{~mL}$ of distilled water.

- Aqueous $\mathrm{NaOH}(10 \%): 10 \mathrm{~g}$ of $\mathrm{NaOH}$ pellet was dissolved in $100 \mathrm{~mL}$ of distilled water.

- Aqueous $\mathrm{NH}_{3}(10 \%): 10 \mathrm{~mL}$ of aqueous $\mathrm{NH}_{3}$ was measured, dissolved in distilled water and made up to $100 \mathrm{~mL}$ mark.

- Aqueous $\mathrm{HNO}_{3}$ (30\%): 30 mLof concentrated $\mathrm{HNO}_{3}$ was measured and made up to mark with distilled water.

\subsection{Phytochemicals Screening}

The extract was subjected to the following standard methods of phytochemical screening (Harborne, 1998; Abo et al., 1999; Kindo et al., 2016) to reveal the presence or absence of the respective classes of metabolites.

- Test for Flavoniods (shinoda's test): The extract $(2 \mathrm{~mL}$ ) was dissolved in $5 \mathrm{~mL}$ of methanol and to these ten 10 drops of diluted hydrochloric acid and small pieces of magnesium were added. No pink, reddish or brown precipitate was formed.

- Test for Flavonoid ( $\mathrm{NaOH}$ test): $0.5 \mathrm{~g}$ of the extract was mixed with distilled water and filtered. To this $2 \mathrm{~mL}$ of $10 \% \mathrm{NaOH}_{(\mathrm{aq})}$ was added which give yellow coloration. The solution became colorless on adding $2 \mathrm{~mL}$ of dilute HCLindicating the presence of flavonoids.

- Test for Flavonoid (FeCL 3 test): The extract $(0.5 \mathrm{~g})$ was mixed with distilled water, boiled and filtered. To $2 \mathrm{~mL}$ filtrate, 3 drops of $10 \% \mathrm{fecl}_{3}$ solution was added.No green-blue or violet coloration indicating the absence of a phenolic group.

- Test for Glycoside (Liebermann's test): The extract $(2 \mathrm{~mL}$ ) was dissolved in $2 \mathrm{~mL}$ of chloroform to which $2 \mathrm{~mL}$ of acetic acid was added and the solution cooled well in Ice. concentrated $\mathrm{H}_{2} \mathrm{SO}_{4}$ was added. Color change from violet to green indicates the presence of a steroid

- Test for Alkaloid (Wagner's test):The extract $(2 \mathrm{ml})$ was acidified with $1.5 \% \mathrm{w} / \mathrm{v}$ of HCL and a few drops of Wagner's reagent was added. No ppt observed.

- Test for alkaloid (Mayer's test): The extract (2ml) was added to few drops of Mayer's reagent. No precipitate observed indicate the absence of alkaloid.

- Test for Triterpenoids (Liebermann-Buchard's test): The dry extract (2mg) was dissolved in acetic anhydride, boiled, cooled and then $1 \mathrm{~mL}$ of concentrated $\mathrm{H}_{2} \mathrm{SO}_{4}$ was added. No formation of color indicates the absence of triterpenoid.

- Test for Saponins (Fronthing's test): The extract (5ml) mixed with a drop of sodium bicarbonate solution $\left(\mathrm{Na}_{2} \mathrm{CO}_{3}\right)$, shaken vigorously and left for 3 minutes. Honeycomb-like froth formed indicates the presence of saponins. 
- Test for Steroids (Salkowski's reaction): The $\left(2 \mathrm{~mL}\right.$ ) of the extract in chloroform, concentrated $\mathrm{H}_{2} \mathrm{SO}_{4}$ was added. No red color was observed indicating the absence of steroids.

- Test for Steroid (Liebermann-Buchard's test): The extract (2mg) was dissolved in acetic anhydride; boiled, cooled, and then $1 \mathrm{~mL}$ of concentrated $\mathrm{H}_{2} \mathrm{SO}_{4}$ was added. Formation of green color indicates the presence of steroid.

- Test for Tannins ( $\mathrm{FeCL}_{3}$, test): The extract $(0.5 \mathrm{~g})$ was dissolved with distilled water, boiled, filtered and to which few drops of $5 \% \mathrm{w} /{ }_{\mathrm{v}} \mathrm{FeCL}_{3}$ solution was added. No color observed indicating the absence of Tannins.

- Test for Anthraquinones (Bontrager's test): Small portion of extract was mixed with $10 \mathrm{~mL}$ of benzene, shaken and filtered. To the filtrate, $5 \mathrm{~mL}$ of $10 \% \mathrm{NH}_{3}$ solution was added, and stirred. No color was observed indicating the absence of Anthraquinon.

\section{Result and Discussion}

\subsection{Percentages Extracted}

Methanol extract yielded $4.6 \mathrm{~g}$ of the extract which was the highest weight, followed by n-hexane extract $4.3 \mathrm{~g}$, dichromethane extract $2.4 \mathrm{~g}$ and ethylacetate extract $1.1 \mathrm{~g}$ as shown in the Table 1

\begin{tabular}{|c|c|c|}
\hline Extracts & Yield of Extracts (G) & Percentage Yield (\%) \\
\hline n-Hexane & 4.3 & 1.79 \\
\hline Dichromethane & 2.4 & 0.99 \\
\hline Ethylacetate & 1.1 & 0.46 \\
\hline Methanol & 4.6 & 1.92 \\
\hline
\end{tabular}

Table 1: Yield of Extracts from Extraction of 240g of Centaurea Senegalensis

\subsection{Phytochemical Screening of the Crude Extracts}

The results of the phytochemical screening of four (4) extracts namely; n-hexane, dichloromethane, ethylacetate and methanol are presented in Table 2. It shows the presence of steroids and glycosides in all the extracts, while triterpenoids and anthraquinones were absent in all the four (4) extracts.

\begin{tabular}{|c|c|c|c|c|}
\hline & N- Hexane Extract & D. C. M Extract & Eythylacetate Extract & Methanol Extract \\
\hline $\begin{array}{c}\text { Alkaloid } \\
\text { (Wagner's test) }\end{array}$ & - & - & - & + \\
\hline $\begin{array}{c}\text { Alkaloid (Mayer's } \\
\text { test) }\end{array}$ & - & - & - & + \\
\hline $\begin{array}{c}\text { Flavonoid } \\
\text { (shinoder's test) }\end{array}$ & - & + & - & ++ \\
\hline $\begin{array}{l}\text { Flavonoid }(\mathrm{NaOH} \\
\text { test })\end{array}$ & ++ & + & - & ++ \\
\hline $\begin{array}{c}\text { Flavonoid } \\
\text { test })\end{array}$ & - & - & - & + \\
\hline $\begin{array}{c}\text { Glycoside } \\
\text { (Liebermann test) }\end{array}$ & + & ++ & + & + \\
\hline $\begin{array}{l}\text { Triterpenoids } \\
\text { (Liebermann- } \\
\text { Buchard test) }\end{array}$ & - & - & - & - \\
\hline $\begin{array}{c}\text { Saponins (frothing } \\
\text { test) }\end{array}$ & + & - & ++ & ++ \\
\hline $\begin{array}{c}\text { Steroid } \\
\text { (Liebermann- } \\
\text { Buchard test) }\end{array}$ & + & + & ++ & ++ \\
\hline $\begin{array}{l}\text { Steroid } \\
\text { (Salkowski } \\
\text { reaction) }\end{array}$ & - & - & + & ++ \\
\hline Tannin (Fecl ${ }_{3}$ test) & - & - & - & ++ \\
\hline $\begin{array}{l}\text { Anthraquinones } \\
\text { (Bontrger's test) }\end{array}$ & - & - & - & - \\
\hline
\end{tabular}

Table 2: Phytochemical Screening of Centaurea Senegalensis Extraction Results

KEY: +t: Present In Large Amount, +. Present in Trace Amount, - : Not Detected

It can be deduced from the result shown in the table above that the solvents in which the metabolites are found in large amount enhanced their extraction as compared with the ones in which they are present in trace amount.

Edeoga et al., (2005) reported that alkaloids, tannins, saponins, triterpenoids and flavonoids were known to show medicinal activity as well as exhibiting physiological activity. They also show anti-oxidant, anti-inflammatory and 
membrane stabilizing property (Perenz et al., 1995). Kam and Liew (2002) reported that alkaloids are known to be the largest group of secondary metabolites in plants. Their presence in significant amount is claimed to have powerful effects on humans and hence could be used as pain killer medications, anti-malaria, anti-microbial, stimulants, anti-diabetic, anticancerous, and anti-oxidants (Duke and Ayensu, 1985; Yahaya et al., 2012). Flavonoids have inherent ability to modify the body reactions to allergens, virus and carcinogens. They show anti-allergic, anti-microbial and anti-cancer activity by which it can be used for different diseases that are generally found in human body. They also help to strengthen capillary walls (Rievere et al., 2009). The presence of tannin is also important, as it forms irreversible complexes with prolin-rich protein, which results in protein synthesis inhibition (Shimadaet al., 2006). Parekhet al. (2007) also reported that tannins react with proteins to provide tanning effect that helps in the treatment of inflamed ulcerated tissues. Most herbs that contain tannin as a major constituent are claimed to be astringent in nature and useful in the treatment of intestinal disorders like diarrhea and dysentery, wounds, sprains, bruises and arresting bleeding (Oghenejobo et al., 2014; Yahayaet al., 2012). Tanins are known to inhibit tumor growth, and hence could be used for cancer prevention. Thus, it can be suggested from the above thatBoswellia dalzieliiis a source of bioactive compound that could have effect on the treatment and prevention of cancer. Tannins also have potential values such as cytotoxic and anti-neoplastic properties (Aguinaldo et al., 2005). Saponins from plants have long been employed for their detergent properties. It is used as mild detergents and in intracellular histochemistry staining to allow antibody access to intracellular proteins. They are used medically in hypercholesterolaemia, hyperglycaemia, antioxidant, anticancer, anti- inflammatory and weight loss etc., (Ngbede et al., 2008). Seigler (1998) reported that saponnins have anticarcinogens' properties, immune modulatory activity and cholesterol lowering activity. It is also been reported to have anti-fungal properties (Sodipo et al., 1991). Some saponins glycosides are cardiotonics while others are contraceptives and precursors for other sex hormones (Evans 2002). Plants steroids have cardiotonic activity, possess insecticidal and anti-microbial properties. It is generally used in herbal medicines and cosmetics. Glycosides are molecules in which a sugar is bound to a non-carbohydrates moiety, usually a small organic molecule. Glycoside can suppress and soothe the irritants dry coughs. They have helpful sedative and relaxant effects on the heart and muscles when taken in small doses and are diuretic (Nwinyi et al., 2004).

\section{Conclusion}

The plant screened for phytochemical constituents proved to have the potential to act as a source of useful drugs and also to improve the health care of the consumers as a result of the presence of various compounds that are vital for good health. These findings suggested that Centaurea senegalensis is an essential source of natural medicine having great importance as therapeutic and curative agent. Centaurea senegalensis can provide useful substrate for the synthesis of new broad-spectrum antibiotics for the treatment of infections caused by the pathogenic organisms. Further purification, identification and characterization of the active compounds would be our priority in later studies.

\section{References}

i. Abo, K. A., LasakiS. W., and Adeyemi, A. A. (1999). Laxative and antimicrobial properties of cassia species growing in Ibadan. Nig. J. Nat. Prod. Med. 8, pp. 47-50.

ii. Aguinaldo, A.M., El-Espeso., Guovara B.Q., Nanoto M.G. (2005). A. Guide book to plant screening phytochemical. University of Santo Tomas, Manila, Philippines.

iii. Doughari, J.H., Human, I.S., Bennade, S. and Ndakidemi, P.A. (2009). Phytochemicals as chemotherapeutic agents and antioxidants: Possible solution to the control of antibiotic resistant verocytotoxin producing bacteria. Journal of Medicinal Plants Research. 3(11): 839-848.

iv. Duke, J. A., and Ayensu, E. S. (1985). Medicinal plants of China. Mich. Reference Publications,

v. Algonae, ISBN: 0917256204.

vi. Edeoga, H. O., Okwu, D. E., and Mbaebie, B. O. (2005). Phytochemical constituents of some

vii. Nigerian medicinal plants. African J. Biotechnol.4(7), 685-688.

viii. Evans, W. C. (2002). Trease and Evans Pharmacognosy. 15th Edition, Elsevier, India.

ix. Harborne, J. B. (1998). Methods of extraction and isolation, In: Phytochemical Methods, Chapman \& Hall, London, pp. 60- 66 .

x. Kalemba and Kunicka. (2003). Antibacterial and Antifungal Properties of Essential Oils. Curr. Med. Chem.10(10), 813-29.

xi. Kam, P. C., Liew, A. (2002). Traditional Chinese herbal medicine and anaesthesia.57(11), 1083-1089.

xii. Kindo, I., Britto, S. J., Marandi, R. R., George, M. and MinjE. (2016). In vitro antibacterial and preliminary phytochemical studies of Andrographis paniculata (Burm. F.) Nees, Asian J. Pharm. Res. 6(1), pp. 7-11.

xiii. Mandal, P., Sinha, S.P., Babu, S., Mandal, N.C. (2005). Antimicrobial activity of Saponins from Acacia auriculiformis. Fitoterapia., 76(5): 462-565.

xiv. Ngbede, J., Yakubu, R. A., and Nyann, D. A. (2008) Phytochemicalscreening for active compounds in canarium schweinfurthii (Atile) leaves from Jos North, Plateau state, Nigeria. Res. J. Biol. Sci. 3 (9), pp. 1076-1078.

xv. Nwinyi, F. C., Binda, L., Ajoku, G. A., Ariagu, S. O. and Gamaniel, K.S. (2004) Evaluation of the aqueous extract of Boswellia dalzielii stem bark for antimicrobial activities and gastrointestinal effects. Afri. J. Biotechnol. 2004; 3:284-288.

xvi. Odebiyi, O.O., Sofowora, E.A. (1978). Phytochemical screening of Nigerian plants, part III. Lloydia, 41, 234-246.

xvii. Oghenejobo, M., Oghenejobo, B. U. S., Uvieghara, K. E., and Omughele, E. (2014). PhytochemicalScreening and Antimicrobial Activities of theFractionated Leaf Extract of CombretumRacemosum, Sch. Acad. J. Pharm.,3(6), 455462. 
xviii. Okigbo R.N., Anuagasi C.L., Amadi J.E., Ukpabi U.J. (2010). Potential inhibitory effects of some African tuberous plant extracts on Escherichia coli, Staphylococcus aureus and Candida albicans. International Journal of Integrative Biology. 6(2): 91-99.

xix. Parekh, J., and Chanda, S. (2007). In-vitroantibacterial Activity of Crude Methanolic Extract of Woodfordia Fruticosa Kurz Flower (Lythacease). Brazilian J. Microbiol., 38, 2-10.

xx. Perenz, R. M., Perenz, S., Zaval, A. M., and Salazar, N. (1995). Anti-inflammatory activity of the bark of Hippocrata excels. J. Ethnopharmacol., 47(1), 85-90.

xxi. $\quad$ Rievere, C., Van, J.H., Nguyen., Peters, L., DejaegherB., HeydenY.V., MinhC.V., Quetin-LeclercqJ. (2009). Polyphenols isolated from antiradical extracts of Mallotus metcalfianus. Phytochemistry. 70: 86-94.

xxii. Seigler, D. S. (1998). Plants with saponins and cardiac glycosides, www.lifwe.vinc.edu/ plantbio/363/ saponinslides.

xxiii. Shimada, T., Koumoto, Y., Li, L., Yamazaki, M., Kondo, M., Nishimura, M., and Hara-Nishimura, I. (2006). A putative component of aretromer complex, is required for the efficient sorting of seed storage proteins. Plant Cell Physiol.,47, 1187-1194.

xxiv. Sodipo, D. A., Akani, M. A., Kolawale, F. B., and Odutuga, A. A. (1991). Saponins as the active antifungal principle in Garcinia kola Heckel seed. Bioscience Research Communication 3, pp. 151.

xxv. Yahaya, O., Yabefa, J. A., Usman, B., Polytechnic, F., State, K., and State, B. (2012). Phytochemical Screening and Antibacterial Activity of Combretum glutinosum Extract against Some Human Pathogens. Br. J. Pharmacol. Toxicol.,3(5), 233-236. 